\title{
Dundee Ready Educational Environment Measure Tool for Evaluating the Educational Environment: A Systematic Review and Meta-analysis
}

\author{
Faraz Ahmed Farooqi ${ }^{1}$, Soban Qadir Khan ${ }^{2}$, Abdul Khabeer $^{3}$, Saqib Ali ${ }^{4 *}$, Asim Al-Ansari ${ }^{5}$ \\ ${ }^{1}$ Department of Academic Affairs, College of Dentistry, Imam Abdulrahman Bin Faisal University, Dammam, Kingdom of Saudi \\ Arabia; ${ }^{2}$ Department of Clinical Affairs, College of Dentistry, Imam Abdulrahman Bin Faisal University, Dammam, Kingdom of \\ Saudi Arabia; ${ }^{3}$ Department of Restorative Dental Sciences, College of Dentistry, Imam Abdulrahman Bin Faisal University, \\ Dammam, Saudi Arabia; ${ }^{4}$ Department of Biomedical Dental Sciences, College of Dentistry, Imam Abdulrahman Bin Faisal \\ University, Dammam, Saudi Arabia; ${ }^{5}$ Department of Preventive Dental Sciences, College of Dentistry, Imam Abdulrahman Bin \\ Faisal University, Dammam, Saudi Arabia
}

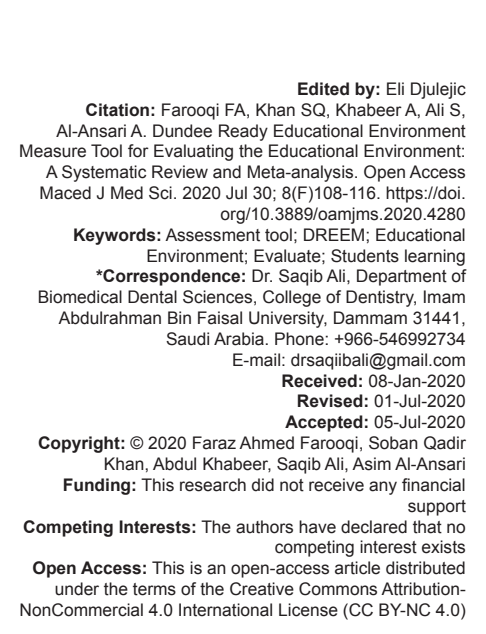

\section{Introduction}

Educational environment can be described as the atmosphere perceived by the students and teachers [1]. This atmosphere can play a key role in the student's ability to learn. Among various factors, engagement of the learner plays an important part and is dependent on their motivation, willingness to learn and perception of subject relevance. This can be further affected by the previous learning experience and the learning place environment. Hutchinson suggests in adult learning theories that teaching is more dependent on setting the atmosphere for learning rather than imparting and sharing knowledge [2]. The environment in which the students' learning plays an important role in their academic progress, behavior, and well-being is most concerning [3]. In achieving a successful curriculum, the educational environment dictates what and how the students learn. Moreover, the perceptions of the students to this curriculum also play a role in the quality of learning. Even though different students perceive learning differently, the feedback in the form of surveys is helpful in evaluating the learning environment.

In 1970, the first tool to evaluate the educational environment was Medical School Learning Environment Survey. Since then, according to a systemic review done in the year 2010, 19 tools have been developed [4]. Various studies have been performed to evaluate the educational environment and students learning [5]. However, these studies have shown different results which can be attributed to the various questionnaires used for the evaluation of the educational environment [4]; therefore, necessitating the need of a globally recognized questionnaire. In 1997, Roff et al. from University of Dundee, Scotland, developed a benchmark tool named Dundee ready educational environment measure (DREEM) [6].

DREEM is a multi-cultural and independent tool useful for assessing the educational environment and student learning. Moreover, it provides with reliable 
feedback regarding the weakness and strength of the educational environment. Since its development, many countries have used this tool to assess the learning environment of their institutions [7].

In the present study, authors reviewed different tools which have been used to evaluate the educational environment and selected DREEM for review as it has been used since long ago. All the articles, which have been published since the start of DREEM tool, had been searched for the study. Collective DREEM score was computed using meta-analysis. Furthermore, variation in DREEM score was studied by distributing the studies into different time intervals.

\section{Materials and Methods}

The PRISMA Guideline for systematics review was used. Literature search was conducted using PubMed and Web of Knowledge (Web of Science) databases. Aim of the literature search was to review all the studies conducted to evaluate the educational environment using DREEM tool and published during 1997 (DREEM was first published) to 2015. Articles were searched using Keywords, "DREEM", "Educational Environment" and "Dundee Ready Educational Environment Measure". Initial search provided 128 articles published during January 1997 to December 2015. Two investigators screened all articles individually: Title, abstract, and full article entitlement for inclusion in the study. The information extracted from the selected articles was name of the first author, publication year, sample size, country of study, overall DREEM score, and standard deviation (SD).

Studies should meet the following inclusion criteria (1) availability of overall mean DREEM score along with standard deviation; (2) sample size must be given; (3) study participants must be the students. These inclusion criteria were applied on 128 articles that used DREEM as an assessment tool. Brief discussion, letters to editor, review summaries, and articles that compared DREEM score with other assessment tools or compared between groups were not included which extracted 56 articles. Among the remaining 56 articles, 13 did not report overall average DREEM score or SD. After the exclusion of those 13 articles, remaining 43 articles were included for analysis (Figure 1).

Comprehensive meta-analysis (version 3) software was used for meta-analysis. Heterogeneity between the studies was assessed by $\left.\right|^{2}$-coefficient and Q-statistics. Where significant heterogeneity existed random effect, model was used. A prominent cause of bias is publication bias. It generally appears because of the studies having a small sample size or large sample size studies which only reported significant results. As we included all studies conducted in various countries, there was a possibility of variation in sample sizes, mean scores, etc. Egger's symmetric test and Begg's funnel plot were used to the study possibility of publication bias. In the absence of publication bias, we assume that studies to be distributed symmetrically and can be verified with the visual inspection of the funnel plot. To determine where the missing studies fall in the plot, we used the Trim and Fill method. Furthermore, two independent samples t-test was employed to study any significant difference in the mean DREEM score while comparing different groups of data.

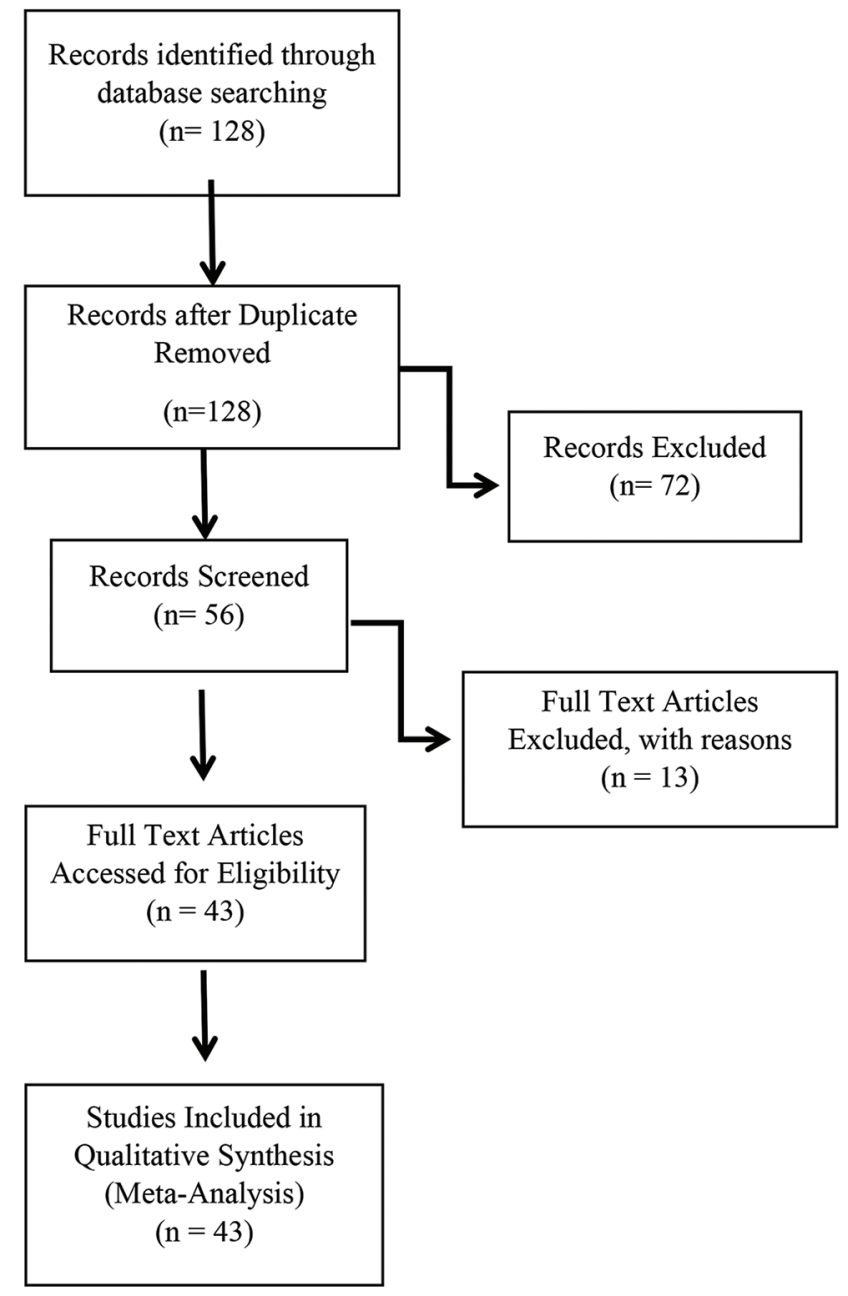

Figure 1: Flow diagram identifying relevant studies

\section{Results}

Total numbers of studies included in the analysis were 41 which were published from 1997 to 2015. These studies were conducted in twenty different countries and the average sample size of a study was 280 (SD =223.15). Considered period for the metaanalysis was spread over 18 years (1997-2015), which was divided into two groups for further analysis. The first group consisted of studies published from 1997 to 2009 and had 13 (30.2\%) studies which passed inclusion criteria. The second group had $30(69.8 \%)$ 
Table 1: Forest plot showing mean and $95 \%$ class interval for all studies

Author (year)
Mayya et al. (2004) [8]

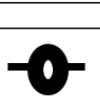

Sobral (2004) [5]

Jiffry et al (2005) [9]

Dunne et al. (2006) [10]

Avalos et al. (2007) [11]

Al Ayed and Sheik (2008) [12]

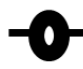

Demiroren et al. (2008) [13]

Tackett et al. (2009) [14]

Tackett et al. (2009) [14]

Tackett et al. (2009) [14]

Bouhaimed et al. (2009) [15]

Carmody et al. (2009) [16]

Riquelme et al. (2009) [17]

Wang et al. (2009) [18]

Aghamolai et al. (2010) [19]

Shehnaz and Sreedharan (2011) [20]

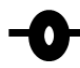

Shehnaz and Sreedharan (2011) [20]

Palmgren and Chandratilake (2011) [21]

Rotthoff et al. (2011) [22]

Sehnaz SI et al. (2012) [23]

Alshehri et al. (2012) [24]

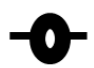

Koohpayehzadeh et al. (2014) [25]

$-0$

Rochmawati et al. (2014) [26]

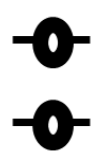

AlFaris et al. (2014) [27]

$-0$

Bakhshi et al. (2014) [28]

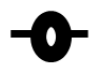

Ousey et al. (2014) [29]
Mean (95\% Cl

$2.15(2.105,2.192)$

$2.46(2.347,2.577)$

$2.15(2.107,2.201)$

$2.48(2.455,2.505)$

$2.6(2.566,2.634)$

$1.8(1.734,1.862)$

$2.35(2.317,2.389)$

$3.11(2.936,3.276)$

$2.87(2.778,2.954)$

$2.77(2.671,2.869)$

$2.12(2.051,2.189)$

$2.98(2.926,3.034)$

$2.55(2.502,2.598)$

$2.65(2.588,2.711)$

$1.99(1.925,2.059)$

$2.33(2.269,2.391)$

$2.71(2.577,2.839)$

$3.14(3.093,3.187)$

$2.2(2.17,2.22)$

$2.7(2.569,2.831)$

$2.26(2.179,2.341)$

$1.92(1.871,1.975)$

$2.62(2.577,2.664)$

$2.37(2.312,2.428)$

$1.88(1.842,1.918)$

$2.28(2.232,2.32)$

$2.7(2.673,2.727)$

$2.71(2.659,2.756)$

$1.77(1.621,1.915)$ 


\section{Table 1: (Continued)}

\begin{tabular}{|c|c|}
\hline Author (year) & Mean $(95 \% \mathrm{Cl})$ \\
\hline Ali et al. (2011) [32] & $2.87(2.8,2.943)$ \\
\hline Ostapczuk et al. (2011) [33] & $2.46(2.417,2.501)$ \\
\hline Kohli and Dhaliwal (2013) [34] & $2.02(1.978,2.067)$ \\
\hline Hamid et al. (2013) [35] & $2.29(2.229,2.343)$ \\
\hline Jawaid et al. (2013) [36] & $2.29(2.256,2.32)$ \\
\hline Shankar et al. (2013) [37] & $2.64(2.531,2.741)$ \\
\hline Doshi et al. (2014) [38] & $2.5(2.455,2.554)$ \\
\hline BuAli et al. (2014) [39] & $2.02(1.929,2.107)$ \\
\hline Pai et al. (2014) [40] & $2.46(2.427,2.493)$ \\
\hline Al-Naggar et al. (2014) [41] & $2.51(2.469,2.543)$ \\
\hline Palmgren et al. (2014) [42] & $3(2.942,3.058)$ \\
\hline Imanipour et al. (2015) [43] & $2.09(2.041,2.135)$ \\
\hline Al-Natour et al. (2015) [44] & $2.56(2.511,2.605)$ \\
\hline Bakhshialiabad et al. (2015) [45] & $2.27(2.231,2.309)$ \\
\hline Karim et al. (2015) [46] & $2.17(2.092,2.256)$ \\
\hline Pelzer et al. (2015) [47] & $2.58(2.467,2.689)$ \\
\hline Overall: $p, 0.001, I^{2}=83.1 \%$ & $2.41(2.399,2.414)$ \\
\hline
\end{tabular}

studies which were published from 2010 to 2015 and passed the inclusion criteria.

Initially, meta-analysis was performed using all 43 articles which passed the inclusion criteria. Table 1 shows the forest plot for the overall mean score for a DREEM item [5], [8], [9], [10], [11], [12], [13], [14], [15], [16], [17], [18], [19], [20], [21], [22], [23], [24], [25], [26], [27], [28], [29], [30], [31], [32], [33], [34], [35], [36], [37], [38], [39], [40], [41], [42], [43], [44], [45], [46], [47]. Visual inspection of forest plot showed presence of heterogeneity and to verify this, Chi-square test was used ( $Q$ statistic: $P=0.00$ ) which reported more than $75 \%$ index of heterogeneity, thus proving the presence of heterogeneity. Therefore, random effect model was used in forest plot. The mean score for a DREEM item through random effect model was found to be 2.426 (95\% confidence interval [CI]: 2.342-2.5209).

To analyze further, the funnel plot was constructed to study the presence of publication bias.
Asymmetry in the funnel plot indicates the presence of publication bias. Symmetry appears when studies plotted evenly on both sides of the plot from top to bottom. Moreover, this symmetry can be observed in Figure 2.

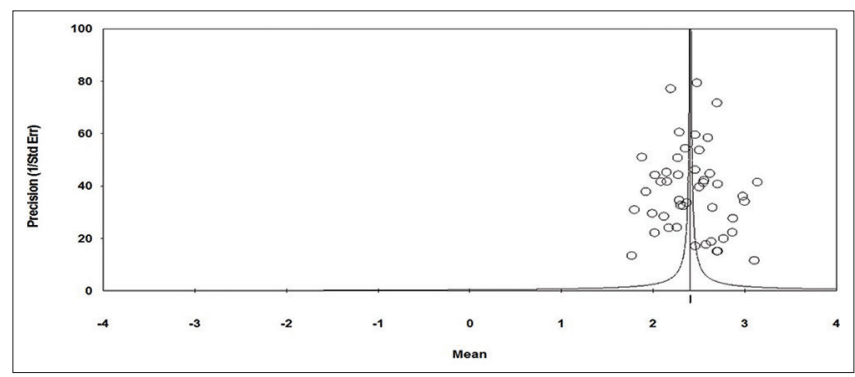

Figure 2: A funnel plot precision by mean. Mean of all studies included in the study (1997-2015)

To assure the absence of publication bias, Egger's and Begg's tests were used. $P$ value obtained from Egger's and Begg's tests was 0.39 and 0.34, respectively, supporting the visual inspection of the 
funnel plot. The "Trim and Fill" method was used to predict the number of studies which were missed during the analysis and the insertion of those studies could enhance the symmetry of the funnel plot. For Figure 3, the Trim and Fill method suggested the inclusion of 3 studies and the computed combined effect from the random effect model was changed from 2.426 to 2.38 .

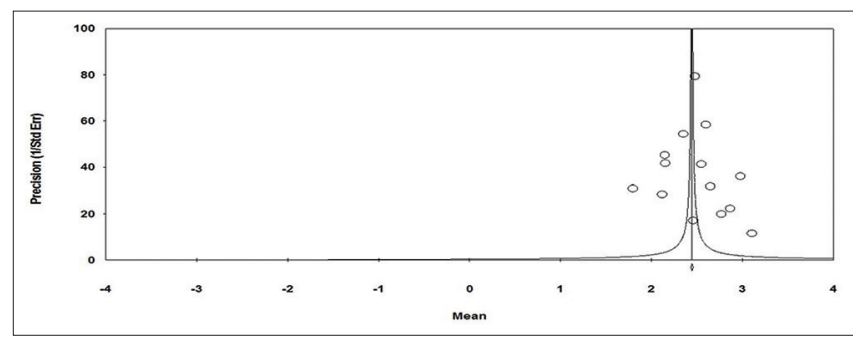

Figure 3: A funnel plot precision by mean. Mean of studies published during 1997-2009

Studies were divided into two groups for analyzing the time effect, the first group was having studies published during 1997 and 2009, and other groups consisted of studies published from 2010 to 2015. Hence, those articles which were published during 2004-2009 were used first to run meta-analysis followed by the studies which were published between 2010 and 2015. For group one, forest plot was constructed from the 13 studies which revealed the presence of heterogeneity (Table 2) and Chi-square test confirmed the presence [5], [8], [9], [10], [11], [12], [13], [14], [15], [16], [17], [18]. $P$ value was significant $(P=0.00)$, along with the high index of heterogeneity (more than $75 \%$ ). The estimated mean from the random effect model was 2.5 (95\% Cl: 2.35-2.64). To evaluate the publication bias in group one, the funnel plot was constructed, and its shape was found to be almost symmetrical (Figure 3). Top and bottom of the plot gave a little touch of asymmetry; otherwise, from the middle, it was symmetrical. Moreover, results from Egger's and Begg's tests also supported the visual inspection with $P$ values of 0.31 and 0.37 , respectively. However, the Trim and Fill method suggested the inclusion of 2 more studies to get the funnel plot more symmetrical and adjusted mean value from the random-effect model will become 2.41 . The difference between the mean of the groups (before and after 2009) was statistically insignificant.

Similarly, the other groups of studies $(n=30)$ published from 2010 to 2015 were analyzed through the meta-analysis. Random effect model was used due to heterogeneity and estimated mean value was 2.39 (95\% Cl: 2.29-2.5) (Table 3) [19], [20], [21], [22], [23], [24], [25], [26], [27], [28], [29], [30], [31], [32], [33], [34], [35], [36], [37], [38], [39], [40], [41], [42], [43], [44], [45], [46], [47]. Significant $P$ value from Chi-square test $(0.00)$ and high index of heterogeneity (more than $70 \%$ ) confirmed the presence of heterogeneity. Shape

Table 2: Forest plot showing mean and 95\% class interval for Group 1 studies (1997-2009)

\begin{tabular}{|c|c|}
\hline $\begin{array}{l}\text { Author (year) } \\
\text { Mayya et al. (2004) [8] }\end{array}$ & $\begin{array}{l}\text { Mean }(95 \% \mathrm{Cl}) \\
2.149(2.105,2.192)\end{array}$ \\
\hline Sobral (2004) [5] & $2.462(2.347,2.577)$ \\
\hline Jiffry et al. (2005) [9] & $2.1545(2.107,2.201)$ \\
\hline Dunne et al. (2006) [10] & $2.48(2.455,2.505)$ \\
\hline Avalos et al. (2007) [11] & $2.6(2.566,2.634)$ \\
\hline Al-Ayed and Sheik et al. (2008) [12] & $1.798(1.734,1.862)$ \\
\hline Demiroren et al. (2008) [13] & $2.353(2.317,2.389)$ \\
\hline Tackett et al. (2009) [14] & $3.106(2.936,3.278)$ \\
\hline Tackett et al. (2009) [14] & $2.866(2.778,2.954)$ \\
\hline Tackett et al. (2009) [14] & $2.77(2.671,2.869)$ \\
\hline Bouhaimed et al. (2009) [15] & $2.12(2.051,2.189)$ \\
\hline Carmody et al. (2009) [16] & $2.98(2.928,3.034)$ \\
\hline Riquelme et al. (2009) [17] & $2.55(2.502,2.598)$ \\
\hline Wang et al. (2009) [18] & $2.65(2.588,2.711)$ \\
\hline Overall: $p, 0.001, I^{2}=83.1 \%$ & $2.445(2.432,2.458)$ \\
\hline
\end{tabular}


of the funnel plot seemed symmetrical (Figure 4) and Trim and Fill method supported $t$ visual analysis of the plot by suggesting no missing study and same results were obtained from Begg's and Egger's test which gave insignificant $P=0.37$ and 0.46 , respectively.

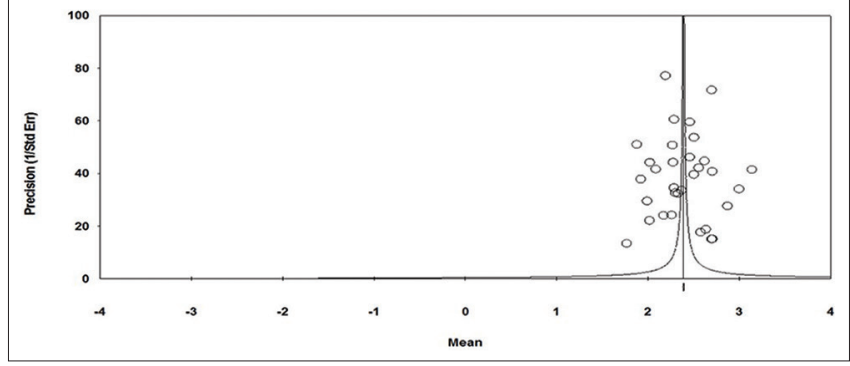

Figure 4: A funnel plot precision by mean. Mean of studies published during 2010-2015

\section{Discussion}

DREEM is repeatedly used to measure the strengths and weaknesses of educational environment of an institute, particularly in medical health professional institutes. After going through all published studies reporting DREEM score, it was found that DREEM has now been used in more than 20 countries and translated in many languages (such as Spanish, Swedish, Turkish Arabic, Chinese, Japanese, and Persian, Portuguese). Of 128 studies reporting DREEM score, only 43 studies were able to pass the inclusion criteria for conducting meta-analysis [5], [8], [9], [10], [11], [12], [13], [14], [15], [16], [17], [18], [19], [20], [21], [22], [23], [24], [25], [26], [27], [28], [29], [30], [31], [32], [33], [34], [35], [36], [37], [38], [39], [40], [41], [42], [43], [44], [45], [46], [47]. Overall, mean DREEM score through random effect model was obtained as 2.4 (C.I, $2.34 \pm 2.52$ ). Among the studies included in the analysis, three reported high DREEM scores, of which two were conducted in Sweden and one in Malaysia, while three studies had DREEM scores <2, among which two were published from Kingdom of Saudi Arabia and one from Iran.

Furthermore, it was observed that the use of DREEM tool increased over the passage of time. Number of studies published before 2009 [5], [8], [9], [10], [11],

Table 3: Forest plot showing mean and 95\% class interval for Group 2 studies (2010-2015)

\begin{tabular}{|c|c|}
\hline Author (year) & Mean $(95 \% \mathrm{Cl})$ \\
\hline Aghamolai et al. (2010) [19] & $1.992(1.925,2.059)$ \\
\hline Shehnaz and Sreedharan (2011) [20] & $2.33(2.269,2.391)$ \\
\hline Shehnaz and Sreedharan (2011) [20] & $2.708(2.577,2.839)$ \\
\hline Palmgren and Chandratilake (2011) [21] & $3.14(3.093,3.187)$ \\
\hline Rotthoff et al. (2011) [22] & $2.195(2.17,2.22)$ \\
\hline Sehnaz Sl et al. (2012) [23] & $2.7(2.569,2.831)$ \\
\hline Alshehri et al. (2012) [24] & $2.26(2.179,2.341)$ \\
\hline Koohpayehzadeh et al. (2014) [25] & $1.923(1.871,1.975)$ \\
\hline Rochmawati et al. (2014) [26] & $2.621(2.577,2.664)$ \\
\hline AlFaris et al. (2014) [27] & $2.37(2.312,2.428)$ \\
\hline AlFaris et al. (2014) [27] & $1.88(1.842,1.918)$ \\
\hline Bakhshi et al. (2014) [28] & $2.276(2.232,2.32)$ \\
\hline Ousey et al. (2014) [29] & $2.7(2.673,2.727)$ \\
\hline Vaughan et al. (2014) [30] & $2.707(2.659,2.756)$ \\
\hline Ahmad et al. (2015) [31] & $1.768(1.621,1.915)$ \\
\hline Ali et al. (2011) [32] & $2.301(2.241,2.361)$ \\
\hline Ali et al. (2011) [32] & $2.872(2.8,2.943)$ \\
\hline
\end{tabular}


Table 3: (Continued)

\begin{tabular}{|c|c|}
\hline Author (year) & Mean $(95 \% \mathrm{Cl})$ \\
\hline Ostapczuk et al. (2011) [33] & $2.459(2.417,2.501)$ \\
\hline Kohli and Dhaliwal (2013) [34] & $2.023(1.978,2.067)$ \\
\hline Hamid et al. (2013) [35] & $2.286(2.229,2.343)$ \\
\hline Jawaid et al. (2013) [36] & $2.288(2.56,2.32)$ \\
\hline Shankar et al. (2013) [37] & $2.636(2.531,2.741)$ \\
\hline Doshi et al. (2014) [38] & $2.505(2.455,2.554)$ \\
\hline BuAli et al. (2014) [39] & $2.018(1.929,2.107)$ \\
\hline Pai et al. (2014) [40] & $2.46(2.427,2.493)$ \\
\hline Al-Naggar et al. (2014) [41] & $2.506(2.469,2.543)$ \\
\hline Palmgren et al. (2014) [42] & $3(2.942,3.058)$ \\
\hline Imanipour et al. (2015) [43] & $2.08(2.041,2.135)$ \\
\hline Al-Natour et al. (2015) [44] & $2.55(2.511,2.605)$ \\
\hline Bakhshialiabad et al. (2015) [45] & $2.27(2.231,2.309)$ \\
\hline Karim et al. (2015) [46] & $2.174(2.092,2.256)$ \\
\hline Pelzer et al. (2015) [47] & $2.578(2.467,2.689)$ \\
\hline Overall: $p, 0.001, l^{2}=83.1 \%$ & $2.399(2.3,2.398)$ \\
\hline
\end{tabular}

[12], [13], [14], [15], [16], [17], [18] were less than half compared to the studies reported during 2010-2015 [19], [20], [21], [22], [23], [24], [25], [26], [27], [28], [29], [30], [31], [32], [33], [34], [35], [36], [37], [38], [39], [40], [41], [42], [43], [44], [45], [46], [47]. However, results from metaanalysis revealed that mean score of the studies before 2009 was higher than the studies performed between 2009 and 2015. One possible reason could be that most of the studies during 2010-2015 were conducted in Asian countries which reported low DREEM scores leading to overall lower mean score for that period.

The presence of high heterogeneity, while constructing forest plot, showed inconsistency among the reporting methods of different studies and can be attributed to the wrong selection of statistical tests or due to the non-statistical background of the authors. These discrepancies in choosing the statistical tool may lead to misinterpretations of results [48]. In 2012, Roff et al. reviewed all the articles which used DREEM as an assessment tool [48]. They highlighted the aim of each study, sample size and 20 statistical tools used for analysis. A lack of uniformity in the statistical methods used for analysis was found through the study. Furthermore, another study conducted a series of simulations with the goal of providing recommendations for how DREEM data could be analyzed and reported in the future [36]. Uniformity in presenting the results and tools for analyzing DREEM data will help in reducing the heterogeneity among the studies. Most of the studies published from Asian countries were performed in recent years. It was observed that less satisfaction levels toward the educational environment could still exist in the institutions. This situation demands attention and actions to improve the educational environment across the institutions located in Asian countries. In addition to this, faculty from other colleges or universities which were having a good educational environment can be invited to help in achieving a better educational environment.

\section{Limitations}

One of the limitations of the study is that only two databases were searched; therefore, increasing the range of databases may lead to more studies reporting DREEM score. Another limitation is that the study did not include subscales of DREEM and inclusion and analysis of subscales might be beneficial in determining the weak and strong areas of health-care teaching institutions. 


\section{Conclusion}

It can be concluded that DREEM has not been used as a predictor for the achievement of any medical college; instead, it can be used to predict high and low achievers in a medical school. This review will help researchers to choose DREEM as a suitable and consistent tool for indicating the learning environment of the institute and student's prerequisites.

\section{References}

1. Al Rukban MO, Khalil MS, Al-Zalabani A. Learning environment in medical schools adopting different educational strategies. Educ Res Rev. 2010;5(3):126-9.

2. Hutchinson L. Educational environment. BMJ. 2003;326(7393):810-2.

PMid:12689981

3. Audin K, Davy J, Barkham M. University quality of life and learning (UNIQoLL): An approach to student well-being, satisfaction and institutional change. J Furt High Educ. 2003;27:365-82. https:// doi.org/10.1080/0309877032000128073

4. Soemantri D, Herrera C, Riquelme A. Measuring the educational environment in health professions studies: A systematic review. Med Teach. 2010;32(12):947-52. https:// doi.org/10.3109/01421591003686229 PMid:21090946

5. Sobral DT. Medical students' self-appraisal of firstyear learning outcomes: Use of the course valuing inventory. Med Teach. 2004:26(3):234-8. https://doi. org/10.1080/0142159042000192028 PMid: 15203500

6. Roff S, McAleer S, Harden RM, Al-Qahtani M, Ahmed AU, Deza $\mathrm{H}$, et al. Development and validation of the Dundee ready education environment measure (DREEM). Med Teach. 1997;19(4):295-9. https://doi.org/10.1037/t34828-000

7. Jamaiah I. Review of research in learning environment. J Health Transl Med. 2008;11(1):7-11.

8. Mayya S, Roff S. Students' perceptions of educational environment: A comparison of academic achievers and under-achievers at Kasturba medical college, India. Educ Health (Abingdon). 2004;17(3):280-91. https://doi. org/10.1080/13576280400002445

PMid: 15848815

9. Jiffry MT, McAleer S, Fernando S, Marasinghe RB. Using the DREEM questionnaire to gather baseline information on an evolving medical school in Sri Lanka. Med Teach. 2005;27(4):34852. https://doi.org/10.1080/01421590500151005 PMid: 16024419

10. Dunne F, McAleer S, Roff S. Assessment of the undergraduate medical education environment in a large UK medical school. Health Educ J. 2006;65:149-58. https://doi. org/10.1177/001789690606500205

11. Avalos G, Freeman C, Dunne F. Determining the quality of the medical educational environment at an Irish medical school using the DREEM inventory. Ir Med J. 2007;100(7):522-5. PMid:17886524

12. Al Ayed $\mathrm{IH}$, Sheik SA. Assessment of the educational environment at the college of medicine of King Saud University,
Riyadh. East Mediterr Health J. 2008;14(4):953-9.

PMid:19166179

13. Demiroren M, Palaoglu O, Kemahli S, Ozyurda F, Ayhan IH Perceptions of students in different phases of medical education of educational environment: Ankara University facuity of medicine. Med Educ Online. 2008;13(1):8. https://doi. org/10.3402/meo.v13i.4477

PMid:20165538

14. Tackett S, Shochet R, Shilkofski NA, Colbert-Getz J, Rampal K, Bakar HA, et al. Learning environment assessments of a single curriculum being taught at two medical schools 10,000 miles apart. BMC Med Educ. 2015;15:105. https://doi.org/10.1186/ s12909-015-0388-0

PMid:26081751

15. Bouhaimed M, Thalib L, Doi SA. Perception of the educational environment by medical students undergoing a curricular transition in Kuwait. Med Princ Pract. 2009;18(3):204-8. https:// doi.org/10.1159/000204351

PMid:19349723

16. Carmody DF, Jacques A, Denz-Penhey H, Puddey I, Newnham JP. Perceptions by medical students of theireducational environment for obstetrics and gynaecology in metropolitan and rural teaching sites. Med Teach. 2009;31(12):e596-602. https:// doi.org/10.3109/01421590903193596

PMid:19995161

17. Riquelme A, Oporto M, Oporto J, Méndez JI, Viviani P, Salech F, et al. Measuring students' perceptions of the educational climate of the new curriculum at the pontificia universidad catolica de chile: Performance of the Spanish translation of the Dundee ready education environment measure (DREEM). Educ Health (Abingdon). 2009;22(1):112

PMid:19953435

18. Wang J, Zang S, Shan T. Dundee ready education environment measure: Psychometric testing with Chinese nursing students. J Adv Nurs. 2009;65(12):2701-9. https://doi. org/10.1111/j.1365-2648.2009.05154.x PMid:19941551

19. Aghamolai T, Fazel I. Medical students' perceptions of the educational environment at an Iranian medical sciences university. BMC Med Educ. 2010;10(1):87. https://doi. org/10.1186/1472-6920-10-87

PMid:21114818

20. Shehnaz SI, Sreedharan J. Students' perceptions of educational environment in a medical school experiencing curricular transition in United Arab Emirates. Med Teach. 2011;33(1):e3742. https://doi.org/10.3109/0142159x.2011.530312 PMid:21182372

21. Palmgren PJ, Chandratilake M. Perception of educational environment among undergraduate students in a chiropractic training institution. J Chiropr Educ. 2011;25(2):151-63. https:// doi.org/10.7899/1042-5055-25.2.151

PMid:22069340

22. Rotthoff T, Ostapczuk MS, De Bruin J, Decking U, Schneider M, Ritz-Timme S. Assessing the learning environment of a faculty: Psychometric validation of the German version of the Dundee ready education environment measure with students and teachers. Med Teach. 2011;33(11):e624-36. https://doi.org/10.3 109/0142159x.2011.610841

PMid:22022916

23. Shehnaz SI, Sreedharan J, Gomathi KG. Faculty and students perceptions of student experiences in a medical school undergoing curricular transition in the United Arab Emirates. Sultan Qaboos Univ Med J. 2012;12(1):77-85. https://doi. org/10.12816/0003091

PMid:22375262 
24. Alshehri SA, Alshehri AF, Erwin TD. Measuring the medical school educational environment: Validating an approach from Saudi Arabia. Health Educ J. 2012;71(5):553-64. https://doi. org/10.1177/0017896912450875

25. Koohpayehzadeh J, Hashemi A, Arabshahi KS, Bigdeli S, Moosavi M, Hatami $\mathrm{K}$, et al. Assessing validity and reliability of Dundee ready educational environment measure (DREEM) in Iran. Med J Islam Repub Iran. 2014;28:60. PMid:25405126

26. Rochmawati E, Rahayu GR, KumaraA. Educational environment and approaches to learning of undergraduate nursing students in an Indonesian school of nursing. Nurse Educ Pract. 2014;14(6):729-33. https://doi.org/10.1016/j.nepr.2014.08.009 PMid:25458532

27. AlFaris EA, Naeem N, Irfan F, Qureshi R, van der Vleuten C. Student centered curricular elements are associated with a healthier educational environment and lower depressive symptoms in medical students. BMC Med Educ. 2014;14(1):192. https://doi.org/10.1186/1472-6920-14-192 PMid:25227417

28. Bakhshi H, Bakhshialiabad MH, Hassanshahi G. Students perceptions of the educational environment in an Iranian medical school, as measured by the Dundee ready education environment measure. Bangladesh Med Res Counc Bull. 2014;40(1):36-41. https://doi.org/10.3329/bmrcb.v40i1.20335 PMid:26118171

29. Ousey K, Stephenson J, Brown T, Garside J. Investigating perceptions of the academic educational environment across six undergraduate health care courses in the United Kingdom. Nurse Educ Pract. 2014;14(1):24-9. https://doi.org/10.1016/j. nepr.2013.06.012

PMid:23871520

30. Vaughan B, Carter A, Macfarlane C, Morrison T. The DREEM, Part 1: Measurement of the educational environment in an osteopathy teaching program. BMC Med Educ. 2014;14:99. https://doi.org/10.1186/1472-6920-14-99 PMid:24884931

31. Ahmad MS, Bhayat A, Fadel HT, Mahrous MS. Comparing dental students' perceptions of their educational environment in Northwestern Saudi Arabia. Saudi Med J. 2015;36(4):477-83. https://doi.org/10.15537/smj.2015.4.10754 PMid:25828286

32. Ali K, McHarg J, Kay E, Moles D, Tredwin C, Coombes L, et al. Academic environment in a newly established dental school with an enquiry-based curriculum: Perceptions of students from the inaugural cohorts. Eur J Dent Educ. 2012;16(2):102-9. https://doi.org/10.1111/j.1600-0579.2011.00728.x PMid:22494309

33. Ostapczuk MS, Hugger A, De Bruin J, Ritz-Timme S, Rotthoff T. DREEM on, dentists! Students' perceptions of the educational environment in a German dental school as measured by the Dundee ready education environment measure. Eur J Dent Educ. 2012;16(2):67-77. https://doi. org/10.1111/j.1600-0579.2011.00720.x PMid:22494304

34. Kohli V, Dhaliwal U. Medical students' perception of the educational environment in a medical college in India: A crosssectional study using the Dundee ready education environment questionnaire. J Educ Eval Health Prof. 2013;10:5. https://doi. org/10.3352/jeehp.2013.10.5

PMid:23967369

35. Hamid B, Faroukh A, Mohammadhosein B. Nursing students' perceptions of their educational environment based on DREEM model in an Iranian University. Malays J Med Sci. 2013;20:56-63.
PMid:24043997

36. Jawaid M, Raheel S, Ahmed F, Aijaz H. Students' perception of educational environment at public sector medical university of Pakistan. J Res Med Sci. 2013;18(5):417-21.

PMid:24174949

37. Shankar PR, Dubey AK, Balasubramanium R. Students perception of the learning environment at Xavier University school of medicine, Aruba. J Educ Eval Health Prof. 2013;10:8. https://doi.org/10.3352/jeehp.2013.10.8 PMid:24223238

38. Doshi D, Reddy BS, Karunakar P, Deshpande K. Evaluating student's perceptions of the learning environment in an Indian dental school. J Clin Diagn Res. 2014;8(11):ZC39-42.

39. BuAli WH, Khan AS, Al-Qahtani MH. Evaluation of hospitallearning environment for pediatric residency in eastern region of Saudi Arabia. J Educ Eval Health Prof. 2015;12:14. https://doi. org/10.3352/jeehp.2015.12.14 PMid:25959654

40. Pai PG, Menezes V, Srikanth AM, Shenoy JP. Medical students perception of their educational environment. J Clin Diagn Res. 2014;8(1):103-7.

PMid:24596737

41. Al-Naggar RA, Abdulghani MT, Al-Kubaisy W, Daher AM, Aripin KN, Assabri A, et al. The Malaysia DREEM: Perceptions of medical students about the learning environment in a medical school in Malaysia. Adv Med Educ Pract. 2014;5:177-84. https:// doi.org/10.2147/amep.s61805

PMid:24959093

42. Palmgren PJ, Lindquist I, Sundberg T, Nilsson GH, Laksov KB. Exploring perceptions of the educational environment among undergraduate physiotherapy students. Int J Med Educ. 2014;5:135-46. https://doi.org/10.5116/ijme.53a5.7457 PMid:25341223

43. Imanipour M, Sadooghiasl A, Ghiyasvandian S, Haghani $H$. Evaluating the educational environment of a nursing school by using the DREEM inventory. Glob J Health Sci. 2015;7(4):211-6. https://doi.org/10.5539/gjhs.v7n4p211

PMid:25946923

44. Al-Natour S. Determining the quality of the medical educational environment at a Saudi medical school using the DREEM inventory. J Am Acad Dermatol. 2015;72(5):AB93. https://doi. org/10.1016/j.jaad.2015.02.385

45. Bakhshialiabad H, Bakhshi M, Hassanshahi G. Students perceptions of the academic learning environment in seven medical sciences courses based on DREEM. Adv Med Educ Pract. 2015;6:195-203. https://doi.org/10.2147/amep.s60570 PMid:25848331

46. Karim J, Al-Halabi YM, Sadeq H, Dawas A, Al-Abdulrazzaq D. The educational environment of the undergraduate medical curriculum at Kuwait University. Adv Med Educ Pract. 2015;6:297-303. https://doi.org/10.2147/amep.s81729 PMid:25897273

47. Pelzer JM, Hodgson JL, Werre SR. Veterinary students' perceptions of their learning environment as measured by the Dundee ready education environment measure. BMC Res Notes. 2014;7:170. https://doi.org/10.1186/1756-0500-7-170 PMid:24661621

48. Miles S, Swift L, Leinster SJ. The Dundee ready education environment measure (DREEM): A review of its adoption and use. Med Teach. 2012;34(9):e620-34. https://doi.org/10.3109/0 $142159 x .2012 .668625$

PMid:22471916 